\title{
Interpersonal Intelligence dan Kreativitas Berpengaruh Terhadap Keterampilan Menulis Puisi
}

\author{
N. Kd. Nina Dwi Cahyanti ${ }^{1}$, M. G. Rini Kristiantari ${ }^{2}$ \\ ${ }^{12}$ Prodi Pendidikan Guru Sekolah Dasar, FIP \\ Universitas Pendidikan Ganesha, \\ Singaraja, Indonesia \\ e-mail: ninadwicahyanti@gmail.com¹, mariagoretirini.kristiantari@undiksha.ac.id²
}

\begin{abstract}
Abstrak
Rendahnya hasil keterampilan puisi siswa disebabkan karena siswa belum memahami bahwa dengan berinteraksi sosial secara optimal dapat memperoleh ide-ide yang dapat dituangkan dalam bentuk puisi sesuai dengan kreativitas sendiri. Penelitian ini bertujuan untuk mengetahui pengaruh yang signifikan interpersonal intelligence dan kreativitas terhadap keterampilan menulis puisi siswa kelas V SD. Penelitian ini merupakan penelitian ex post facto. Populasi dari penelitian ini adalah seluruh siswa kelas V di SD yang berjumlah 208 orang siswa. Sampel ditetapkan dari populasi menggunakan teknik proportional random sampling. Jumlah sampel dari penelitian ini adalah 136 orang siswa. Metode pengumpulan data dalam penelitian ini menggunakan metode tes penugasan dan metode non tes. Analisis data yang digunakan yaitu dengan teknik analisis regresi linier sederhana dan teknik analisis regresi linier ganda setelah semua uji prasyarat terpenuhi. Berdasarkan hasil analisis yang terlah dilakukan, maka dapat disimpulkan bahwa, interpersonal intelligence berpengaruh terhadap keterampilan menulis puisi dibuktikan berdasarkan nilai $\mathrm{F}_{\text {hitung }}=$ $4,06>F_{\text {tabel }}=3,91$ dan pengaruhnya sebesar $3,5 \%$, kreativitas berpengaruh terhadap keterampilan menulis puisi dibuktikan berdasarkan nilai $F_{\text {hitung }}=6,88>F_{\text {tabel }}=3,91$ dan pengaruhnya sebesar $3,3 \%$, interpersonal intelligence dan kreativitas terhadap keterampilan menulis puisi dibuktikan berdasarkan nilai $F_{\text {hitung }}=3,60>F_{\text {tabel }}=3,07$ dan pengaruhnya sebesar $6,2 \%$. Implikasi dari hasil penelitian ini adalah bahwa lingkungan sekolah berperan penting dalam pembentukan interpersonal intelligence yang positif dan peningkatan kreativitas yang dimiliki oleh siswa, karena lingkungan yang mengajarkan siswa sebagai individu untuk mengembangkan minat dan bakatnya sesuai kemampuan yang dimilikinya.
\end{abstract}

Kata kunci: menulis puisi, interpersonal intelligence, kreativitas

\begin{abstract}
The low results of students' poetry skills are caused because students do not yet understand that by optimally interacting socially they can get ideas that can be expressed in the form of poetry in accordance with their own creativity. This study aims to determine the significant effect of interpersonal intelligence and creativity on poetry writing skills of fifth grade elementary school students. This research is an ex post facto research. The population of this study was all fifth grade students in elementary school, totaling 208 students. The sample is determined from the population using proportional random sampling technique. The number of samples from this study were 136 students. Data collection methods in this study used the assignment test method and the non-test method. Analysis of the data used is simple linear regression analysis techniques and multiple linear regression analysis techniques after all the prerequisite tests are met. Based on the results of the analysis that has been done, it can be concluded that, interpersonal intelligence influences poetry writing skills proven based on the value of Fcount $=4.06>$ Ftable $=3.91$ and the effect is $3.5 \%$, creativity influences the poetry writing skill is proven based on the value Fcount $=6.88>$ Ftable $=3.91$ and the effect is $3.3 \%$, interpersonal intelligence and creativity for poetry writing skills are proven based on the value of Fcount $=3.60>$ Ftable $=3.07$ and the effect is $6.2 \%$. The implication of the results of this study is that the school environment plays an important role in the formation of positive
\end{abstract}

\footnotetext{
*Corresponding author.
}

Received 20 April 2020, Accepted 20 Juni 2020; Available online 5 Juli 2020 (C) 2020 MI All Rights Reserved 
interpersonal intelligence and increased creativity owned by students, because the environment teaches students as individuals to develop their interests and talents according to their abilities.

Keywords: poetry writing, interpersonal intelligence, creativity

\section{Pendahuluan}

Sastra merupakan salah satu karya yang mengandung unsur seni dan cermin kehidupan yang mampu memantulkan nilai-nilai yang ada dalam masyarakat (Sri Defi \& Hana Pebriana, 2019). Pengajaran sastra di sekolah dasar menekankan pada bagaimana upaya siswa untuk lebih banyak menekuni karya-karya sastra. Dengan menekuni karya-karya sastra siswa mengenal langsung hasil karya sastra untuk peningkatan keterampilan berbahasa dan sastra Indonesia, serta dengan menekuni karya-karya sastra siswa mendapatkan berbagai manfaat dari kehidupannya (Wahyuni, 2016). Pembelajaran apresiasi sastra bertujuan agar siswa mampu mengapresiasi dan berekspresi sastra melalui kegiatan mendengarkan, membaca, melisankan serta menuliskan hasil sastra yang diperoleh sesuai dengan pengalaman dalam bentuk cerita dan puisi (Nurgiyantoro, 2009).

Kegiatan menuliskan hasil sastra menjadi kegiatan yang kurang menarik hati siswa sehingga siswa kurang suka dengan menulis sastra. Hal ini sejalan dengan penelitian Monawati (2015) yang menyatakan bahwa siswa kurang tertarik dengan menulis sastra dikarenakan siswa tidak paham dengan berbagai macam manfaat yang didapatkan dari menulis sastra, tidak tahu untuk apa kegiatan menulis tersebut, merasa tidak memiliki bakat dalam hal menulis, serta tidak mengetahui cara awal dalam hal menulis sastra. Dengan menulis sastra, siswa diharapkan untuk mampu berapresiasi sastra secara kreatif. Kegiatan berapresiasi sastra sangat bermanfaat bagi siswa. Manfaat berapresiasi sastra pada siswa adalah agar mampu secara kreatif melakukan pengenalan realita, pengembangan kemampuan berbahasa, pengembangan kemampuan memahami bentuk hubungan sosial, maupun pengembangan kemampuan memahami diri sendiri dan orang lain (Sukma, 2017).

Berapresiasi sastra melalui kegiatan menulis dapat memberikan kepuasan untuk siswa dalam berekspresi sesuai dengan kreativitas yang dimiliki siswa (Marlani, 2019). Maka dari itu, menulis sastra harus diperhatikan, sebab dapat mendukung siswa dalam meningkatan kecerdasan dan menumbuhkan kreativitas siswa (Deden Ardiansyah \& Suryana, 2018). Menulis sastra terdapat beberapa bentuk salah satunya yaitu menulis dalam bentuk puisi (Wicaksono, 2019). Puisi yang termasuk sastra dikatakan sebagai hasil dari ungkapan perasaan atau apa yang dirasakan dari suatu pengalaman yang dituangkan dengan bentuk bahasa tulis yang memiliki keindahan serta bersifat imajinatif (Sulkifli, 2016). Secara umum, kegiatan menulis puisi dapat dirumuskan sebagai bentuk pengungkapan bahasa yang merupakan gambaran pengalaman imajinatif, emosional, dan intelektual penyair dengan menggunakan teknik-teknik tertentu sehingga mampu menimbulkan perasaan tertentu bagi pembaca atau pun pendengar (Jaya, 2013). Puisi dikatakan sebagai bahasa perasaan. Hal ini sejalan dengan penelitian Gustina \& Pebriana (2019) yang menyatakan bahwa puisi disebut sebagai pernyataan seorang penyair pernyataan itu berisi pengalaman batinnya sebagai hasil proses kreatif terhadap objek seni.

Keterampilan menulis puisi merupakan suatu kemampuan dalam hal mengungkapkan suatu pikiran terhadap orang lain dengan menggunakan bahasa tulis yang bersifat kesastraan (Laeli, 2017). Permaknaan yang diungkapkan melalui karya puisi merupakan makna dari melihat sisi lain kehidupan, kemudian merasakannya dan nantinya disampaikan dalam bentuk bahasa tulis yaitu salah satunya dalam bentuk puisi (Nurgiyantoro, 2018). Selain itu, (Kanza, 2018) menyatakan bahwa keterampilan menulis puisi merupakan suatu kemampuan dalam menyampaikan gagasan, pendapat, dan perasaan dalam bahasa tulis serta mengekspresikan pemikiran yang membangkitkan perasaan imajinasi pancaindera dalam susunan irama, sajak, dan kata kiasan ditulis sebagai ekspresi seseorang yang tidak 
terikat oleh beberapa aturan khusus, yaitu jumlah baris tiap bait, jumlah suku kata tiap baris, isi, dan pilihan kata.

Latihan dan praktik sangat diperlukan dalam membina keterampilan menulis puisi. Menurut (Mulyati, 2017) menulis puisi juga dapat sebagai media dalam menuangkan ide-ide yang dimiliki siswa atau dengan menulis puisi sesuai dengan bagaimana keadaan suasana hati, niat dan pengalaman sosial yang siswa dapatkan sesuai dengan kreativitas masingmasing. Menulis puisi dikatakan sebagai pelatihan kecerdasan yang artinya suatu aktivitas yang menginginkan seseorang untuk benar-benar intelek dalam memahami bahasa, mempunyai wawasan yang luas, dan sensitif dengan perasaannya (Danang, 2016). Menulis puisi tidak hanya berpatokan pada bahasa yang indah, tetapi harus juga memperhatikan unsur-unsur yang lain sehingga mendapatkan hasil puisi yang berkualitas atau puisi yang baik.

Berdasarkan hasil pengamatan yang dilakukan bahwa hasil keterampilan menulis puisi siswa di kelas V SD Negeri Gugus V DR.Soetomo tergolong rendah. Siswa masih sulit dalam mecari ide-ide yang akan dituangkan dalam bentuk puisi. Tidak hanya itu, siswa juga sulit dalam mengembangkan ide-ide yang ia punya untuk dapat membuat suatu karya sastra dalam bentuk puisi. Ide-ide yang diperlukan siswa bisa bersumber dari kecerdasan siswa dalam membina hubungan sosialnya dan bagaimana siswa bisa mengembangkan kreativitasnya dalam bentuk puisi, hal tersebut bisa menyebabkan kurang optimalnya siswa dalam menulis puisi. Hal ini juga sejalan dengan penelitian Asri (2019) yang menyebutkan bahwa dengan memiliki teman banyak, senang dalam bergaul, disenangi oleh orang-orang yang ada di lingkungan tersebut dapat menambah ide-ide atau gagasan yang kita miliki dari pengalaman sehingga dapat menuangkannya dalam bentuk puisi sesuai dengan kreativitas sendiri dan pengalaman sendiri.

Faktor yang disinyalir mempengaruhi keterampilan puisi pada siswa adalah interpersonal intelligence. Kecerdasan interpersonal intelligence memiliki peranan yang penting bagi kehidupan, karena kecerdasan ini perlu diberi kesempatan dan rangsangan oleh lingkungan agar dapat berkembang (Juniarti, 2018). Interpersonal intelligence adalah kecerdasan yang dimiliki untuk membentuk hubungan dengan orang lain, mempertahannkannya dan menempatkan diri dalam hubungan tersebut sehingga mampu mengetahui karakter seseorang (Monawati, 2015). Selain itu, Amstrong (2009:25) mengatakan bahwa interpersonal intelligence (kecerdasan interpersonal) adalah keahlian dalam mengetahui apa yang dirasakan orang lain. Sedangkan menurut Sholeh (2016:30) menyatakan bahwa kecerdasan intrapersonal adalah kemampuan diri untuk berpikir kritis secara reflektif, yaitu mengacu pada kesadaran reflektif mengenai perasaan dan proses mengenai pemikiran diri sendiri. Terdapat beberapa faktor yang mempengaruhi interpersonal intelligence adalah lingkungan keluarga, diri anak itu sendiri dan pengalaman hidup individu (Agustini et al., 2019). Adapun kegiatan yang mencakup kegiatan ini adalah berpikir, merancang tujuan, refleksi merenung, membuat jurnal dan menilai diri. Interpersonal Intelligence menjadi hal penting bagi hasil keterampilan menulis puisi karena interpersonal intelligence yang mempengaruhi keterampilan menulis puisi siswa (Jaenudin, 2016). Interpersonal intelligence dapat dikatakan sebagai kecerdasan bergaul atau kecerdasan sosial yang penting distimulasi untuk perkembangan anak (Safaria, 2005). Sehubungan dengan pernyataan (Nurtika, 2018) bahwa Interpersonal intelligence memiliki peranan yang penting untuk dikembangkan sejak dini. Mengingat siswa sekolah dasar adalah sebagai generasi penerus dan nantinya sebagai pemimpin masa depan, maka seharusnya layak mendapatkan pendidikan dan bimbingan untuk mengembangkan interpersonal intelligence sejak dini, sebagai upaya preventif atas hambatan-hambatan yang ada dalam dunia sosialnya pada masa yang akan datang. Siswa yang memiliki interpersonal intelligence mempunyai keahlian dalam mimiliki rasa empati pada orang lain, memiliki kemampuan berorganisasi dengan sekelompok orang untuk mencapai tujuan bersama, mampu mengetahui apa yang dirasakan orang lain, mampu berteman dan menjalin komunikasi yang baik (Afifah, 2019). 
Faktor lainnya yang juga dapat mempengaruhi keterampilan menulis puisi siswa yaitu kreativitas. Menurut (Hosnan, 2017) mengungkapkan kreativitas adalah keterampilan dalam menemukan hal yang baru atau mengkombinasikan antara unsur yang telah ada sebelumnya. Windyarini (2019:35) juga memberikan ungkapan jika kreativitas adalah meletakkan sesuatu bersama dalam cara yang baru, mengamati sesuatu yang lain, yang mungkin terlewatkan, membangun sesuatu yang baru, bekerja untuk membuat suatu hal yang menarik dan sejenisnya. Kreativitas siswa adalah suatu keahlian dalam menemukan hingga menciptakan sesuatu hal baru yang nantinya dapat bermanfaat untuk siswa Komaidi (2011:73). Sesuatu hal yang baru bukan berarti tidak ada sebelumnya namun sesuatu hal yang memiliki nilai inovatif dan kreatif yang ditemukan oleh siswa (Fitriana et al., 2017). Menurut (Aziz, 2018) hakikat dari kreativitas adalah suatu kegiatan mengembangkan kemampuan kreatif untuk menemukan banyak ide. Hal ini dikatakan sebagai berpikir divergen. Siswa yang memiliki kreativitas rendah lebih cenderung menulis puisi hanya untuk melengkapi atau melaksanakan tugas semata. Hal ini dapat dilihat hasil karya yang mereka buat. Kemudian siswa yang memiliki kreativitas tinggi mampu menghasilkan karya baru yang dapat mengejutkan (Tahir \& Marniati, 2018). Kreativitas juga merupakan sebuah proses, yakni proses belajar untuk mencari jalan termudah terhadap permasalahan yang dihadapi (Mukti, 2019). Faktor yang disinyalir dapat mempengaruhi keterampilan menulis puisi yaitu interpersonal intelligence dan kreativitas harus dioptimalkan dengan cara memberikan waktu untuk selalu berlatih dalam keterampilan menulis puisi.

Penelitian ini bertujuan untuk mengetahui pengaruh yang signifikan interpersonal intelligence terhadap keterampilan menulis puisi siswa kelas V SD Negeri Gugus V DR.Soetomo Kecamatan Denapasar Selatan, untuk mengetahui pengaruh yang signifikan kreativitas terhadap keterampilan menulis puisi siswa kelas V SD Negeri Gugus V DR.Soetomo Kecamatan Denapasar Selatan dan untuk mengetahui pengaruh yang signifikan interpersonal intelligence dan kreativitas terhadap keterampilan menulis puisi siswa kelas V SD Negeri Gugus V DR.Soetomo Kecamatan Denapasar Selatan.

\section{Metode}

Penelitian ini merupakan penelitian Ex Post Facto karena penelitan ini bertujuan untuk mengetahui pengaruh yang signifikan interpersonal intelligence dan kreativitas terhadap keterampilan menulis puisi siswa kelas V SD Negeri Gugus V DR.Soetomo Kecamatan Denpasar Selatan.

Populasi dalam penelitian ini adalah siswa kelas V SD Negeri Gugus V DR.Soetomo Kecamatan Denpasar Selatan yang terdiri dari 6 kelas dalam 4 sekolah dasar negeri. Jumlah populasi yang terdapat di SD Negeri Gugus V DR.Soetomo Kecamatan Denpasar Selatan adalah 208 orang siswa dan jumlah sampel yang telah ditentukan pada tabel berjumlah 136 orang siswa. Pengambilan sampel dalam penelitian ini menggunakan teknik proporsional random sampling yang artirnya teknik pengambilan sampel secara acak dengan memperhatikan jumlah siswa dari masing-masing kelas sesuai dengan proporsi yang terdapat didalam populasi tersebut.

Metode yang digunakan dalam pengumpulan data adalah metode teknik tes dan non tes. Jenis teknik tes yang digunakan yaitu tes menulis puisi dan teknik non tes yang digunakan dalam penelitian ini yaitu kuesioner. Data keterampilan menulis puisi diperoleh melalui hasil dari tulisan siswa dalam membuat puisi dengan tema bebas sesuai dengan pengalaman sendiri. Data interpersonal intelligence dan kreativitas diperoleh melalui penyebaran kuesioner.

Kuesioner interpersonal intelligence sebagai alat ukur untuk mengetahui interpersonal intelligence yang dimiliki siswa. Angket interpersonal intelligence dibuat berdasarkan beberapa indikator meliputi (1) sikap empati, (2) sikap pro-sosial, (3) kesadaran diri, (4) pemahaman situasi sosial, (5) etika sosial, (6) keterampilan dalam pemecahan masalah, (7) komunikasi efektif. Jumlah item kuesioner yaitu 35 butir pernyataan. Pengujian instrumen 
dalam penelitian ini menggunakan uji validitas dan uji reliabilitas. Kuesioner yang digunakan dalam mengukur interpersonal intelligence ini menggunakan kuesioner skala likert.

Data kreativitas siswa diperoleh melalui penyebaran kuesioner. Kuesioner kreativitas dibuat berdasarkan beberapa indikator meliputi (1) mengemukakan banyak gagasan, (2) menghasilkan gagasan yang bervariasi, (3) mengembangkan gagasan, (4) merinci gagasan secara detail dan (5) menghasilkan gagasan yang tidak biasa. Jumlah item kuesioner yaitu 30 butir pernyataan. Pengujian instrumen dalam penelitian ini menggunakan uji validitas dan uji reliabilitas. Kuesioner yang digunakan dalam mengukur kreativitas ini menggunakan kuesioner skala likert.

Data keterampilan menulis puisi siswa diperoleh melalui hasil tes menulis puisi dengan tema bebas. Penilaian hasil menulis puisi siswa dinilai berdasarkan beberapa indikator meliputi (1) tema, (2) diksi, (3)amanat, (4) rima.

Uji prasyarat analisis menggunakan uji normalitas, uji linearitas, uji multikolinieritas dan uji heteroskedastisitas. Setelah seluruh uji prasyarat terpenuhi, maka dilanjutkan menguji hipotesis dengan menggunakan teknik analisis regresi linier sederhana dan regresi linier ganda dengan hipotesis yang di uji adalah $\mathrm{H}_{0}$ (1) tidak terdapat pengaruh yang signifikan interpersonal intelligence terhadap keterampilan menulis puisi siswa kelas $V$ SD Negeri Gugus V DR.Soetomo Kecamatan Denpasar Selatan, (2) tidak terdapat pengaruh yang signifikan kreativitas terhadap keterampilan menulis puisi siswa kelas V SD Negeri Gugus V DR.Soetomo Kecamatan Denpasar Selatan, (3) tidak terdapat pengaruh yang signifikan interpersonal intelligence dan kreativitas terhadap keterampilan menulis puisi siswa kelas $\mathrm{V}$ SD Negeri Gugus V DR.Soetomo Kecamatan Denpasar Selatan.

\section{Hasil dan Pembahasan}

Data dalam penelitian ini berupa skor yang diperoleh melalui lembaran angket interpersonal intelligence dan kreativitas, serta tes keterampilan menulis puisi dengan tema bebas sesuai dengan pengalaman sendiri. Dengan demikian data penelitian ini dikelompokkan atas tiga kelompok. Satu kelompok data terkait dengan variabel terikat $(Y)$ dan dua kelompok data yang terkait dengan variabel bebas $\left(X_{1}\right.$ dan $\left.X_{2}\right)$. Ketiga data tersebut dideskripsikan dalam bentuk distribusi frekuensi yang terdiri atas skor tertinggi, skor terendah, mean, median, modus, standar variasi, dan varian. Hasil analisis data ketiga variabel dapat dilihat pada tabel di bawah ini dan dipaparkan secara lengkap.

Tabel 01. Hasil Uji Statistik Deskripsi Data

\begin{tabular}{llccc}
\hline No & \multicolumn{1}{c}{ Statistik } & $\begin{array}{c}\text { Interpersonal } \\
\text { Intelligence }\end{array}$ & Kreativitas & $\begin{array}{c}\text { Keterampilan } \\
\text { Menulis Puisi }\end{array}$ \\
\hline 1. & Skor Tertinggi & 131 & 117 & 100 \\
\hline 2. & Skor Terendah & 85 & 71 & 35 \\
\hline 3. & Mean & 111,96 & 91,38 & 68,74 \\
\hline 4. & Median & 111,8 & 91,8 & 69,46 \\
\hline 5. & Modus & 111,8 & 89,6 & 76,48 \\
\hline 6. & Satandar Deviasi & 7,48 & 9,21 & 15,42 \\
\hline 7. & Varian & 55,95 & 84,82 & 237,78
\end{tabular}

Dari hasil analisis yang telah dilakukan terhadap data, seluruh data yang masuk memenuhi syarat untuk diolah dan dianalisis. Berikut rincian data dari ketiga variabel dalam penelitian ini. 
Tabel 02. Distribusi Frekuensi Data Penelitian

\begin{tabular}{ccccccccc}
\hline \multicolumn{1}{c}{$\begin{array}{c}\text { Keterampilan Menulis } \\
\text { Puisi (Y) }\end{array}$} & \multicolumn{2}{c}{$\begin{array}{l}\text { Interpersonal Intelligence } \\
\left(\mathbf{X}_{\mathbf{1}}\right)\end{array}$} & \multicolumn{2}{c}{ Kreativitas $\left(\mathbf{X}_{2}\right)$} \\
\hline Skor & F & F. Kumulatif & Skor & F & F. Kumulatif & Skor & F & Kumulatif \\
\hline $30-38$ & 1 & 1 & $85-90$ & 1 & 1 & $70-75$ & 5 & 5 \\
\hline $39-47$ & 16 & 17 & $91-96$ & 4 & 5 & $76-81$ & 9 & 14 \\
\hline $48-56$ & 15 & 32 & $97-102$ & 20 & 25 & $82-87$ & 32 & 46 \\
\hline $57-65$ & 25 & 57 & $103-108$ & 26 & 51 & $88-93$ & 41 & 87 \\
\hline $66-74$ & 25 & 82 & $109-114$ & 31 & 82 & $94-99$ & 24 & 111 \\
\hline $75-83$ & 27 & 109 & $115-120$ & 27 & 109 & $100-105$ & 15 & 126 \\
\hline $84-92$ & 20 & 129 & $121-126$ & 16 & 125 & $106-111$ & 9 & 135 \\
\hline $93-101$ & 7 & 136 & $127-132$ & 11 & 136 & $112-117$ & 1 & 136 \\
\hline & $\mathbf{1 3 6}$ & & & $\mathbf{1 3 6}$ & & & $\mathbf{1 3 6}$ & \\
\hline
\end{tabular}

Sebelum melakukan analisis uji hipotesis, terlebih dahulu dilakukan uji asumsi diantaranya, uji normalitas, linearitas, multikolinearitas, dan uji heteroskedastisitas. Hasil uji ini dapat dilihat pada tabel berikut.

Tabel 03. Uji Normalitas Data Interpersonal Intelligence, Kreativitas dan Keterampilan Menulis Puisi

\begin{tabular}{cccc}
\hline Variabel & $\begin{array}{c}\text { Nilai } \\
\text { maksimum } \\
\mathbf{F}_{\mathbf{T}}-\mathbf{F}_{\mathbf{S}} \mid\end{array}$ & $\begin{array}{c}\text { Nilai tabel } \\
\text { Kolmogorov- } \\
\text { Smirnov }\end{array}$ & Keterangan \\
\hline Interpersonal Intelligence & 0,066 & 0,117 & Berdistribusi normal \\
\hline Kreativitas & 0,078 & 0,117 & Berdistribusi normal \\
\hline Keterampilan Menulis Puisi & 0,091 & 0,117 & Berdistribusi normal \\
\hline
\end{tabular}

Tabel 03 menunjukkan bahwa nilai maksimum | FT - FS | dari residual data interpersonal intelligence terhadap keterampilan menulis puisi $=0,066<$ nilai tabel Kolmogorov - Smirnov $=0,117$ maka residual data berdistribusi normal. Nilai maksimum | FT - FS | dari residual data kreativitas terhadap keterampilan menulis puisi $=0,078<$ nilai tabel Kolmogorov - Smirnov $=0,117$ maka residual data berdistribusi normal. Nilai maksimum | FT - FS | dari residual data interpersonal intelligence dan kreativitas terhadap keterampilan menulis puisi $=0,091<$ nilai tabel Kolmogorov - Smirnov $=0,117$ maka residual data berdistribusi normal.

Tabel 04. Uji Linearitas Data Interpersonal Intelligence dan Kreativitas Terhadap Keterampilan Menulis Puisi

\begin{tabular}{cccc}
\hline Variabel & $\mathbf{F}_{\text {hitung }}$ & $\mathbf{F}_{\text {tabel }}$ & Keterangan \\
\hline $\begin{array}{c}\text { Interpersonal Intelligence terhadap } \\
\text { Keterampilan Menulis Puisi }\end{array}$ & 4,06 & 3,91 & Signifikan \\
\hline $\begin{array}{c}\text { Kreativitas terhadap Keterampilan } \\
\text { Menulis Puisi }\end{array}$ & 6,88 & 3,91 & Signifikan \\
\hline
\end{tabular}


Tabel 04 menunjukkan bahwa nilai data interpersonal intelligence terhadap keterampilan menulis puisi yaitu $F_{\text {hitung }}=4,06>F_{\text {tabel }}=3,91$ dengan taraf signifikansi $5 \%$ maka $F$ regresi tersebut signifikan. Perhitungan data kreativitas terhadap keterampilan menulis puisi memperoleh hasil $F_{\text {hitung }}=6,88>F_{\text {tabel }}=3,91$ dengan taraf signifikansi $5 \%$ maka $F$ regresi tersebut signifikan.

Tabel 05. Uji Multikolinieritas Data Interpersonal Intelligence dan Kreativitas Terhadap Keterampilan Menulis Puisi

\begin{tabular}{cccc}
\hline Variabel & Tolerance & VIF & Keterangan \\
\hline $\begin{array}{c}\text { Interpersonal } \\
\text { Intelligence }\end{array}$ & 0,718 & 1,393 & Tidak terjadi multikolinieritas \\
\hline Kreativitas & 0,718 & 1,393 & Tidak terjadi multikolinieritas \\
\hline
\end{tabular}

Tabel 05 menunjukkan nilai Tolerance $=0,718$ lebih dari 0,1 dan nilai VIF $=1,393$ berarti kurang dari 10, hal ini berarti bahwa tidak terjadi multikolinieritas antar variabel bebas.

Tabel 06. Uji Heteroskedastisitas Data Interpersonal Intelligence dan Kreativitas Terhadap Keterampilan Menulis Puisi

\begin{tabular}{ccc}
\hline Variabel & Sig. & Keterangan \\
\hline Interpersonal Intelligence & 0,973 & Tidak terjadi heteroskedastisitas \\
\hline Kreativitas & 0,582 & Tidak terjadi heteroskedastisitas \\
\hline
\end{tabular}

Tabel 06 menunjukkan bahwa nilai signifikansi kedua variabel independen yaitu interpersonal intelligence $=0,973>$ taraf signifikansi $=0,05$ dan kreativitas $=0,582>$ taraf signifikansi $=0,05$. Sehingga dapat disimpulkan bahwa tidak terjadi masalah heteroskedastisitas pada model regresi.

Setelah dilakukan uji prasyarat analisis maka pengujian hipotesis menggunakan analisis uji regresi linier sederhana dan analisis uji regresi linier ganda dapat dilakukan. Hasil uji hipotesis ini dapat dilihat pada tabel berikut.

Tabel 07. Hasil Uji Hipotesis Ketiga Variabel

\begin{tabular}{lccccccc}
\hline \multicolumn{1}{c}{ Variabel } & $\begin{array}{c}\text { Garis } \\
\text { Regresi }\end{array}$ & $\begin{array}{c}\text { Koefisien } \\
\text { Korelasi } \\
\mathbf{r}_{\mathbf{x y}}\end{array}$ & $\begin{array}{c}\text { Taraf } \\
\text { Signifikansi }\end{array}$ & $\mathbf{d k}$ & $\mathbf{r}_{\text {tabel }}$ & $\begin{array}{c}\text { Koefisien } \\
\text { Determinasi }\end{array}$ & Ket \\
\hline $\begin{array}{l}\text { Interpersonal } \\
\text { intelligence } \\
\text { terhadap }\end{array}$ & $\begin{array}{c}\hat{Y}=36,92 \\
+0,28 \mathrm{X}_{1}\end{array}$ & 0,187 & $5 \%$ & 13 & 0,159 & 0,035 & $\begin{array}{c}\text { Signifikan } \\
\text { dan linier }\end{array}$ \\
$\begin{array}{l}\text { keterampilan } \\
\text { menulis puisi }\end{array}$ & & & & 4 & & & \\
\hline $\begin{array}{l}\text { Kreativitas } \\
\text { terhadap } \\
\text { keterampilan } \\
\text { menulis puisi }\end{array}$ & $\begin{array}{c}73,469+ \\
0,020 \mathrm{X}_{2}\end{array}$ & 0,181 & $5 \%$ & 13 & 0,159 & 0,033 & $\begin{array}{c}\text { Signifikan } \\
\text { dan linier }\end{array}$ \\
\hline $\begin{array}{l}\text { Interpersonal } \\
\text { intelligence } \\
\text { dan }\end{array}$ & $\begin{array}{r}\hat{Y}=21,61 \\
+0,334 \mathrm{X}_{1}\end{array}$ & 0,249 & $5 \%$ & 13 & 0,159 & 0,062 & $\begin{array}{c}\text { Signifikan } \\
\text { dan linier }\end{array}$ \\
\hline
\end{tabular}




\author{
kreativitas $\quad+0,107 \mathrm{X}_{2}$ \\ terhadap \\ keterampilan \\ menulis puisi
}

Tabel 07 menunjukkan pengujian hipotesis pertama dengan analisis regresi linier sederhana diperoleh persamaan garis regresi $Y^{\prime}=36,92+0,28 X_{1}$ signifikan dan linier. Hubungan interpersonal intelligence $\left(\mathrm{X}_{1}\right)$ dengan keterampilan menulis puisi $(\mathrm{Y})$ ditunjukkan oleh koefisien korelasi $r_{x y}=0,187$. Berdasarkan uji koefisien korelasi pada taraf signifikansi $5 \%$ dengan $\mathrm{dk}=134$ diperoleh $r_{\text {tabel }}=0,159$ maka dengan demikian $r_{\text {hitung }}=0,187>r_{\text {tabel }}=$ 0,159 ini berarti korelasi interpersonal intelligence dengan keterampilan menulis puisi memiliki hubungan positif. Koefisien determinasi adalah $R^{2}=0,035$ dan pengaruhnya sebesar 3,5\% variasi keterampilan menulis puisi ditentukan oleh interpersonal intelligence. $\mathrm{Hal}$ ini menandakan bahwa $\mathrm{H}_{0}$ yang menyatakan tidak terdapat pengaruh yang signifikan interpersonal intelligence terhadap keterampilan menulis puisi siswa kelas V SD Negeri Gugus V DR.Soetomo Kecamatan Denpasar Selatan ditolak dan $\mathrm{H}_{\mathrm{a}}$ yang menyatakan terdapat pengaruh yang signifikan interpersonal intelligence terhadap keterampilan menulis puisi siswa kelas V SD Negeri Gugus V DR.Soetomo Kecamatan Denpasar Selatan diterima.

Pengujian hipotesis kedua menggunakan analisis uji regresi linier sederhana diperoleh persamaan garis regresi $\hat{Y}=73,469+0,020 X_{2}$ signifikan dan linier. Hubungan kreativitas $\left(X_{2}\right)$ dengan keterampilan menulis puisi $(Y)$ ditunjukkan oleh koefisien korelasi $r_{x y}=0,181$. Berdasarkan uji koefisien korelasi pada taraf signifikansi $5 \%$ dengan $\mathrm{dk}=134$ diperoleh $\mathrm{r}_{\text {tabel }}$ $=0,159$ maka dengan demikian $r_{\text {hitung }}=0,181>r_{\text {tabel }}=0,159$ ini berarti korelasi kreativitas dengan keterampilan menulis puisi memiliki hubungan positif. Koefisien determinasi adalah $R^{2}=0,033$ dan pengaruhnya sebesar $3,3 \%$ variasi keterampilan menulis puisi ditentukan oleh kreativitas. Hal ini menandakan bahwa $\mathrm{H}_{0}$ yang menyatakan tidak terdapat pengaruh yang signifikan kreativitas terhadap keterampilan menulis puisi siswa kelas V SD Negeri Gugus V DR.Soetomo Kecamatan Denpasar Selatan ditolak dan $\mathrm{H}_{\mathrm{a}}$ yang menyatakan terdapat pengaruh yang signifikan kreativitas terhadap keterampilan menulis puisi siswa kelas V SD Negeri Gugus V DR.Soetomo Kecamatan Denpasar Selatan diterima.

Pengujian hipotesis ketiga menggunakan analisis uji regresi linier ganda diperoleh persamaan garis regresi $Y=21,61+0,334 X_{1}+0,107 X_{2}$ signifikan dan linier. Hubungan interpersonal intelligence $\left(\mathrm{X}_{1}\right)$ dan kreativitas $\left(\mathrm{X}_{2}\right)$ dengan keterampilan menulis puisi $(\mathrm{Y})$ ditunjukkan oleh koefisien korelasi $r_{x y}=0,249$. Berdasarkan uji koefisien korelasi pada taraf signifikansi $5 \%$ dengan $\mathrm{dk}=134$ diperoleh $\mathrm{r}_{\text {tabel }}=0,159$ maka dengan demikian $\mathrm{r}_{\text {hitung }}=0,249$ $>r_{\text {tabel }}=0,159$ ini berarti korelasi interpersonal intelligence dan kreativitas secara bersamasama dengan keterampilan menulis puisi memiliki hubungan positif. Koefisien determinasi adalah $R^{2}$ dengan hasil 0,062 dan kontribusinya sebesar $6,2 \%$ variasi keterampilan menulis puisi ditentukan oleh interpersonal intelligence dan kreativitas. Hal ini menandakan bahwa $\mathrm{H}_{0}$ yang menyatakan tidak terdapat pengaruh yang signifikan interpersonal intelligence dan kreativitas terhadap keterampilan menulis puisi siswa kelas V SD Negeri Gugus V DR.Soetomo Kecamatan Denpasar Selatan ditolak dan $\mathrm{H}_{\mathrm{a}}$ yang menyatakan menyatakan terdapat pengaruh yang signifikan interpersonal intelligence dan kreativitas terhadap keterampilan menulis puisi siswa kelas V SD Negeri Gugus V DR.Soetomo Kecamatan Denpasar Selatan diterima.

Berdasarkan hasil yang sudah didapatkan, pengaruh interpersonal intelligence dan kreativitas terhadap keterampilan menulis puisi siswa kelas V SD Negeri Gugus V DR.Soetomo Kecamatan Denpasar Selatan adalah sebesar 6,2\%. Hal ini menunjukkan bahwa tidak hanya interpersonal intelligence dan kreativitas yang mempengaruhi keterampilan menulis puisi, namun juga terdapat faktor-faktor lain yang mempengaruhi keterampilan menulis puisi siswa kelas V SD Negeri Gugus V DR.Soetomo sebesar 93,8\%, baik itu faktor dari dalam diri siswa (minat siswa, bakat siswa, motivasi siswa dan disiplin diri 
siswa dalam belajar berlatih) maupun dari luar diri siswa (faktor guru, faktor teknik dan media dalam proses pembelajaran, faktor lingkungan dan orang tua).

Pada penelitian ini menunjukkan bahwa interpersonal intelligence berhubungan dengan keterampilan menulis puisi, kreativitas berhubungan dengan keterampilan menulis puisi, dan interpersonal intelligence dan kreativitas berhubungan dengn keterampilan menulis puisi siswa. Interpersonal intelligence dikatakan sebagai kecerdasan membangun jalinan relasi atau hubungan, membentuk serta mempertahankan hubungan sosial sehingga mendapatkan situasi yang saling menguntungkan (Safaria, 2005). Interpersonal intelligence yang positif dan maksimal dalam kecerdasan ini membuat siswa senang menjalin komunikasi, menjalin hubungan, mampu memahami apa yang yang orang lain rasakan, dan senang memiliki teman yang banyak. Siswa yang memiliki interpersonal intelligence yang positif mampu berkerja sama, berinteraksi dan berkomunikasi dengan orang lain secara optimal. Dengan berinteraksi dan berkomunikasi dengan orang lain secara optimal, siswa bisa mendapatkan ide-ide yang bermakna sesuai dengan pengalaman yang didapatkan yang bisa digunakan sebagai bahan menulis puisi untuk melatih keterampilan menulis puisi siswa. Jadi dapat disimpulkan bahwa semakin tinggi interpersonal intelligence yang dimiliki siswa, maka semakin tinggi juga keterampilan menulis puisi siswa.

Selain itu, kreativitas juga berpengaruh terhadap keterampilan menulis puisi siswa. Kreativitas adalah hasil nyata interaksi antara individu dan lingkungannya, kemampuan untuk membuat kombinasi baru, berdasarkan data, informasi, atau unsur-unsur yang sudah ada atau dikenal sebelumnya, yaitu semua pengalaman dan pengetahuan yang telah diperoleh seseorang selama hidupnya baik itu di lingkungan sekolah, keluarga, maupun dari lingkungan masyarakat (Zamhuri, 2017). Siswa yang memiliki kreativitas tinggi pasti akan senang dengan pekerjaan yang susah, cenderung akan menemukan jawaban yang terbaik, belajar lebih mandiri, terbuka dan memiliki toleransi kepada orang lain. Kreativitas harus selalu dikembangkan, dilatih dan diwujudkan dalam bentuk nyata. Membangkitkan kreativitas siswa dapat memberikan pengaruh yang cukup besar terhadap keterampilan siswa yang salah satunya keterampilan dalam menulis puisi. Semakin tinggi kreativitas yang dimiliki siswa maka semakin tinggi juga hasil keterampilan menulis puisi siswa. Maka dari itu, siswa yang memiliki interpersonal intelligence dan kreativitas yang tinggi akan berdampak pada hasil keterampilan menulis puisi siswa.

(Muhammad et al., 2018) menyatakan bahwa terdapat hubungan antara kecerdasan interpersonal dan berpikir kreatif secara bersama dengan hasil menulis siswa Kelas V SD Negeri di Kabupaten Kebumen. Keeratan hubungan antara kecerdasan interpersonal dan berpikir kreatif secara bersama dengan hasil menulis siswa Kelas V SD Negeri di Kabupaten Kebumen sebesar 10,18\%. Persamaan kajian penelitian tersebut dengan penelitian ini yaitu variabel bebas yaitu kecerdasan interpersonal dan berpikir kreatif, populasinya yaitu siswa kelas V SD. Perbedaannya yaitu pada variabel terikat dan tempat pelaksanaan. Variabel terikat pada penelitian tersebut adalah hasil menulis siswa sedangkan pada penelitian ini variabel terikatnya yakni keterampilan menulis puisi. Di tempat penelitian tersebut di SD Negeri di Kabupaten Kebumen sedangkan tempat penelitian ini di SD Negeri Gugus V DR.Soetomo Kecamatan Denpasar Selatan.

Penelitian relevan lainnya yaitu penelitian oleh (Booty, 2018) menyatakan bahwa terdapat hubungan yang signifikan antara kreativitas dengan hasil belajar Bahasa Indonesia siswa kelas V di MI Ma'had Islamy Palembang Tahun ajaran 2017-2018. Persamaan penelitian terletak pada variabel bebasnya. Variabel bebas yang digunakan yaitu kreativitas. Persamaan lainnya yaitu populasinya sama-sama kelas V SD. Adapun perbedaan penelitian tersebut terletak pada variabel terikat dan tempat penelitiannya. Variabel terikat pada penelitian tersebut adalah hasil belajar siswa pada mata pelajaran Bahasa Indonesia sedangkan variabel terikat pada penelitian ini adalah keterampilan menulis puisi. Tempat penelitian tersebut di Mi Ma'had Islamy Palembang sedangkan tempat penelitian dalam penelitian ini di SD Negeri Gugus V DR.Soetomo Kecamatan Denpasar Selatan. 
Penelitian relevan lainnya yaitu penelitian oleh (Kartikosari \& Setyawan, 2018) menyatakan bahwa hubungan kecerdasan interpersonal dengan intensi perundungan yang didapatkan adalah terdapat hubungan negatif yang signifikan antara kecerdasan interpersonal dengan intensi perundungan. Adapun persamaannya di variabel bebas yaitu kecerdasan interpersonal. Adapun perbedaan penelitian tersebut terletak di variabel terikat, populasi dan tempat pelaksanaannya. Variabel terikat pada penelitian tersebut adalah intensi perundungan sedangkan variabel terikat pada penelitian ini adalah keterampilan menulis puisi. Populasi pada penelitian tersebut adalah siswa kelas VIII dan IX sedangkan populasi di penelitian ini adalah siswa kelas V SD. Tempat penelitian tersebut di SMP H.Isriati Semarang sedangkan tempat penelitian dalam penelitian ini di SD Negeri Gugus V DR.Soetomo Kecamatan Denpasar Selatan.

\section{Simpulan}

Berdasarkan analisis yang telah dilaksanakan maka dapat disimpulkan bahwa 1) terdapat pengaruh yang signifikan interpersonal intelligence terhadap keterampilan menulis puisi siswa Kelas V SD Negeri Gugus V DR.Soetomo Kecamatan Denpasar Selatan dan pengaruhnya sebesar $3,5 \%$. 2) terdapat pengaruh yang signifikan kreativitas terhadap keterampilan menulis puisi siswa Kelas V SD Negeri Gugus V DR.Soetomo Kecamatan Denpasar Selatan dan pengaruhnya sebesar 3,3\%. 3) terdapat pengaruh yang signifikan interpersonal intelligence dan kreativitas terhadap keterampilan menulis puisi siswa Kelas $\mathrm{V}$ SD Negeri Gugus V DR.Soetomo Kecamatan Denpasar Selatan dan pengaruhnya sebesar $6,2 \%$.

Sebagai tindak lanjut dari hasil penelitian, maka penelitian ini disarankan kepada (1) kepada siswa disarankan agar terus menerus melatih keterampilan menulis puisi sehingga dapat mengasah keterampilan dalam menulis hal-hal lain yang terkait dengan ilmu pengetahuan dan teknologi, (2) kepada guru disarankan agar secara rutin membimbing siswa untuk melatih keterampilan menulis puisi dalam pembelajaran bahasa Indonesia dan hal-hal yang terkait dengan menulis puisi, (3) Kepada kepala sekolah disarankan agar membuat kebijakan untuk membina para guru agar secara proporsional memberikan pengetahuan keterampilan mengenai menulis puisi kepada peserta didik, (4) Kepada peneliti lain disarankan untuk melakukan penelitian yang lebih mendalam mengenai keterampilan menulis puisi dan menambah variabel-variabel lain yang terkait dengan hasil penelitian ini.

\section{Daftar Pustaka}

Afifah, M. (2019). Korelasi Kecerdasan Interpersonal, Intrapersonal dan Kecerdasan Emosi Siswa Kelas V SD Muhammadiyah Ponorogo. Muslim Heritage, Vol.3, No.

Agustini, A., Awang, I. S., \& Parida, L. (2019). Kecerdasan Interpersonal Peserta Didik di Sekolah Dasar. VOX EDUKASI: Jurnal IImiah IImu Pendidikan, 10(2), 120-128. https://doi.org/10.31932/ve.v10i2.519

Amstrong, T. (2009). Setiap Anak Cerdas. Terj. Rina Buntaran. Gramedia Pustaka Utama.

Aziz, R. (2018). Creative Learning. Edulitera.

Booty. (2018). Hubungan Kreativitas Dengan Hasil Belajar Siswa Kelas V Mata Pelajaran Bahasa Indonesia Di Mi Ma'had Islamy Palembang. JIP(Jurnal IImiah PGMI), Vol. 4 No.1

Danang, W. (2016). Peningkatan Keterampilan Menulis Puisi Menggunakan Media Gambar Pada Siswa Kelas V SD Negeri Suryodiningratan 2. Pendidikan Guru Sekolah Dasar, 514-523. journal.student.uny.ac.id/ojs/index.php/pgsd/article/download/2061/1762

Deden Ardiansyah, S., \& Suryana, Y. (2018). Meningkatkan Keterampilan Menulis Puisi Bebas Menggunakan Teknik Pancingan Kata Kunci di Kelas. In All rights reserved (Vol. 
5, Issue 1). http://ejournal.upi.edu/index.php/pedadidaktika/index

Fitriana, M., Hasibuan, \& Trijaya. (2017). Meningkatkan Kreativitas dan Motivasi Belajar Siswa Melalui Pembelajaran Kooperatif Student Teams Achievement Division (STAD) Pada Materi Persegi dan Persegi Panjang. Jurnal Mantik Penusa, 1(2), 70-75.

Gustina, H., \& Pebriana, Z. (n.d.). Nomor 1 Tahun 2019 Halaman 12-25 JURNAL PENDIDIKAN dan KONSELING Research \& Learning in Faculty of Education (Vol. 1).

Hosnan. (2017). Pengembangan Kreativitas Siswa Dalam Proses Pembelajaran di Kelas V SD Negeri 3 Rokan IV Koto. Jurnal IImu Pendidikan Sosial,Sains Dan Humoniora, 3.

Jaenudin, R. (2016). Analisis Kecerdasan Interpersonal Peserta Didik Pada Pembelajaran Ekonomi di Kelas X SMA Negeri 2 Tanjung Raja. Jurnal Profit, Vol. 3 No.

Jaya, S. (2013). Peningkatan Keterampilan Menulis Puisi Melalui Media Gambar Siswa Kelas X.1 SMA Negeri 2 Kota Sungai Penuh. Bahasa, Sastra Dan Pembelajaran, Vol. 1 No.1

Juniarti, Y. (2018). Peningkatan Kecerdasan Interpersonal Anak Usia Dini Melalui Media Celemek Pintar. Jurnal Audi, UNISRI. http://ejurnal.unisri.ac.id/index.php/jpaud

Kanza, V., Kurniaman, O., \& Witri, G. (2018). Pengaruh Penggunaan Media Gambar Dua Dimensi Terhadap Kemampuan Menulis Puisi Bebas Siswa Kelas V SD Negeri 161 Pekanbaru PGSD FKIP Universitas Riau. PAJAR, Vol.2 No.6(Universitas Riau).

Kartikosari, R., \& Setyawan, I. (2018). Hubungan Kecerdasan Interpersonal Dengan Intensi Perundungan Pada Siswa Sekolah Menengah Pertama H. Isriati Semarang. 7(April), 182-188.

Komaidi, D. (2011). Panduan Lengkap Menulis Kreatif Teori dan Praktek. Sabda Media.

Laeli. (2017). Peningkatan Keterampilan Menulis Puisi Keindahan Alam Menggunakan Metode Partisipatori Dengan Media Gambar. Jurnal Pendidikan Bahasa dan Sastra Indonesia. http://journal.unnes.ac.id/sju/index.php/jpbsi

Monawati. (2015). Hubungan Antara Kecerdasan Interpersonal Dengan Prestasi Belajar. Jurnal Pesona Dasar, 3 No.3.

Muhammad, Azis, A. A., \& Ngitung, R. (2018). Hubungan Kecerdasan Naturalistik, Kecerdasan Interpersonal dan Kecerdasan Intrapersonal dengan Hasil Belajar Biologi Siswa Kelas XI IPA SMA Negeri di Kota Makassar. UNM Journal of Biological Education, 2.

Mukti, D. F. (2019). Peningkatan Kreativitas dan Hasil Belajar Siswa Melalui Pendekatan Kontekstual di Kelas V Sekolah Dasar. Jurnal Pendidikan Madrasah Ibtidaiyah, Vol.2 No.

Mulyati, S. N. (2017). Peningkatan Kemampuan Menulis Puisi Bebas Dengan Menggunakan Media Audio Visual. E-Jurnal Literasi, 1 No.1.

Nurgiyantoro, B. (2009). Penilaian Dalam Pengajaran Bahasa dan Sastra. BPFE.

Nurgiyantoro, B. (2018). Sastra Anak. Gadjah Mada University Press.

Nurtika, E. (2018). Analisis Perkembangan Kecerdasan Interpersonal Anak dengan Metode Bermain Peran. Jurnal Pendidikan Raudhatul Athfal, Vol. 2 No.

Safaria, T. (2005). Interpersonal Intelligence Metode Pengembangan Kecerdasan Interpersonal Anak. Amara Books.

Salamah, E. R. (2017). Media Cerita Bergambar untuk Meningkatkan Keterampilan Menulis Puisi Anak. PEDAGOGIA: Jurnal Pendidikan, 6(1), 43. 
https://doi.org/10.21070/pedagogia.v6i1.616

Sholeh, K. (2016). Kecerdasan Majemuk Berorientasi Pada Partisipasi Peserta Didik. Pustaka Pelajar.

Sri Defi, R., \& Hana Pebriana, P. (2019). Peningkatan Keterampilan Menulis Puisi Dengan Menggunakan Model Active Learning Teknik Card Sort Kelas V SDTI 030 Batu Belah. Jurnal Pendidikan Dan Konseling, 1 No. 1.

Sukma, E. (n.d.). Peningkatan Kemampuan Menulis Puisi Siswa Kelas V Sd Negeri Sumbersari lii Malang Dengan Strategi Pemetaan Pikiran (Vol.3).

Sulkifli. (2016). Kemampuan Menulis Puisi Siswa Kelas VIII SMP Negeri Satu Atap 3 Langgikima Kabupaten Konawe Utara.

Tahir, T., \& Marniati, M. (2018). Pengaruh Kreativitas terhadap Prestasi Belajar Matematika Siswa ditinjau dari Jenis Kelamin (Studi Kasus di MAN 1 Kolaka). Journal of Medives: Journal of Mathematics Education IKIP Veteran Semarang, 2(2), 279. https://doi.org/10.31331/medives.v2i2.656

Wahyuni, T. (2016). Peningkatan Keterampilan Menulis Puisi Menggunakan Kartu Kata Bagi Siswa SMP Negeri 1 Jumo Temanggung. https://panjiamboro.wordpress.com

Wicaksono, A., Worowirastri Ekowati, D., Muhammadiyah Malang, U., \& Purwantoro, S. (n.d.). Modifikasi Menggunakan Media Gambar Pada Siswa Kelas IV SDN Purwantoro 2 Malang. TIRU.

Windyarini, S. (2019). Pembelajaran Berbasis Konteks \& Kreativitas. Deepublish Publisher.

Zamhuri, A. (2017). Pengaruh Kreativitas Siswa dan Fasilitas Belajar Terhadap Prestasi Belajar Pendidikan Agama Islam di SMAN se Kecamatan Xiii Koto Kampar Kabupaten Kampar. In Jurnal Pendidikan Islam (Vol. 6). 